Received:

$1-X-2020$

Accepted:

$4-X \mid I-2020$

Published Online:

$1-||-2021$

\section{Characterization of Allergic Manifestations in Dental Professionals}

\section{Caracterización de manifestaciones alérgicas de profesionales en Odontología}

Jorge Oviedo-Quirós DDS, OMFS, MSD1; Luis Madriz-Montero MD, DDS2; Patricia Lorz-Ulloa DDS, POS ${ }^{3}$

1. Unidad de Labio Paladar Hendido-Craneomaxilofacial, Hospital Nacional de Niños "Dr. Carlos Sáenz Herrera". Facultad de Odontología, Universidad de Costa Rica, Costa Rica. https://orcid.org/0000-0003-0211-5939

2. Facultad de Odontología, Universidad de Costa Rica, Costa Rica. https://orcid.org/0000-0001-7700-4390 3. Facultad de Odontología, Universidad de Costa Rica, Costa Rica. https://orcid.org/0000-0002-0692-9537

Correspondence to: Dr. Jorge Oviedo-Quirós - jorge.oviedo@ucr.ac.cr

ABSTRACT: The aim was to determine the prevalence and types of the allergies present among dental professionals in Costa Rica. We performed a cross-sectional study on 664 dentists who completed a self-reported questionnaire. A descriptive cross-sectional study with inferential analysis was carried out. Dentists reported allergies prior to studying dentistry in 39\% of cases, 36\% reported chronic illnesses, and $61 \%$ of the dentists reported first-degree relatives with some type of allergic reaction. Different allergies had a similar prevalence among the dental professionals (ranging between 19\%-26\%), all allergic manifestations occurred within the first 120 minutes after exposure. The average time of exposure to dentistry-related environments was 16 years $(95 \% \mathrm{Cl}$ ) among all the dentists surveyed. There is a positive correlation between the presence of a chronic illness and the predisposition to develop allergic reactions among dentists. In addition, there is a directly proportional relationship between age, time of exposure to dental environments, and the risk of developing allergic conditions to dental materials. The main adverse reactions reported due to exposure to dental materials, medicines and/or food were gastrointestinal, skin, and respiratory problems.

KEYWORDS: Allergy; Atopy; Odontology; Health professionals; Dentist; Dental materials. 
RESUMEN: El objetivo del estudio fue determinar la prevalencia y tipo de alergias presentes entre los odontólogos en Costa Rica. Se realizó un estudio transversal descriptivo en 664 dentistas que completaron un cuestionario, utilizando análisis inferencial para el procesamiento de los resultados. Los odontólogos reportaron alergias previo a estudiar odontología en un 39\% de los casos, el 36\% informó enfermedades crónicas y el $61 \%$ de los dentistas mencionó tener familiares en primer grado que habían presentado algún tipo de reacción alérgica. Diferentes tipos de alergias tuvieron una prevalencia similar entre los odontólogos (oscilando entre el $19 \%$ y el $26 \%$ ), todas las manifestaciones alérgicas ocurrieron dentro de los primeros 120 minutos después de la exposición al alergeno. El tiempo medio de exposición a entornos relacionados con la odontología fue de 16 años (IC del 95\%) entre todos los dentistas encuestados. Existe una correlación positiva entre la presencia de una enfermedad crónica y la predisposición a desarrollar reacciones alérgicas entre los dentistas. Además, existe una relación directamente proporcional entre edad, tiempo de exposición a entornos dentales, y el riesgo de desarrollar reacciones alérgicas a los materiales dentales. Las principales reacciones adversas notificadas posterior a la exposición a materiales dentales, medicamentos y/o alimentos fueron problemas gastrointestinales, cutáneos y respiratorios.

PALABRAS CLAVE: Alergia; Atopia; Odontología; Profesionales de la salud; Dentista; Materiales dentales.

\section{INTRODUCTION}

Dentistry professionals are in daily contact with many different types of dental materials, either during patient care or laboratory work. Such materials contain potential allergens that can potentially trigger an allergic reaction, which may impact everyday activities. It is crucial to understand how allergies come to be, given that they affect approximately $25 \%$ of the population in developed countries. In the United States of America (USA) alone, 54\% of the population has had at least one allergic reaction. Importantly, the prevalence of allergy seems to be on the rise (1). An allergy can be defined as an abnormal and exaggerated immune reaction that occurs when an exogenous substance is recognized as an allergen, to which other people do not normally present a reaction (2). The term "hypersensitivity" refers to an excessive or inadequate immune response to environmental antigens, usually non-pathoge- nic, that causes tissue inflammation and organic malfunctions (3-7).

Hypersensitivity reactions were described by Gell and Coombs in 1963 and classified into four distinct clinical and immunological manifestations: types I, II, III, and IV (8, 9-14). Type I, II, and III reactions are rapid (from minutes to a few hours after re-exposure to an antigen), whereas type IV reactions require 24 to 48 hours to manifest, so they are referred to as delayed hypersensitivity reactions $(8-9,14)$.

According to recent studies, the incidence of allergic reactions to dental materials has been increasing. Some of these materials include local anesthetics, latex, cement, acrylics, and adhesives (15-20). For example, latex gloves can cause allergic dermatitis (15). Allergic dermatitis represents approximately $30 \%$ of environment-related occupational dermatoses (21). Many of the 
materials mentioned above are mixed with acrylates that contain inhibitors (e.g., hydroquinone), activators (e.g., tertiary amines), crosslinking agents (e.g., formaldehyde, responsible for inflammatory allergic reactions in patients with acrylic dentures), and initiators (e.g., benzoyl peroxide), which have been shown to be sensitizing substances (17-18,22-24).

It is important to address food and drug allergies, given that there has been cross-reactivity between certain foods and latex and certain foods and some medications (25,26,27-32). In dentistry, the use of a wide variety of materials has increased the frequency of allergic reactions during consultations (33-34).

This research may be useful for the development of appropriate measures in the work environment since the development of allergic manifestations can affect the professional and personal life of dentists. The study aimed to determine the prevalence and characteristics of the different kinds of atopy present in dentists working in Costa Rica.

\section{MATERIALS AND METHODS}

\section{BIBLIOGRAPHIC RESEARCH}

A search and analysis of the literature related to the subject was made using PubMed and Google Scholar, as well as databases available at the University of Costa Rica (UCR) Library System for Documentation and Information (SIBDI). The search keywords that were used included: alginate, allergies, allergic, allergy, asthma, atopy, chlorhexidine, conjunctivitis, cross-reactivity, dental materials, dental stone, dentists, dermatitis, dermal, dermatological, drug reactions, food allergies, health care worker, hypersensitivity, immune system, latex, latex-fruit syndrome, lidocaine, local anesthetics, medications, methacrylate, prevalence, pathophysiology, and rhinitis.

\section{STUDY POPULATION}

The study population consisted of a cohort of 664 dentists surveyed at the academic congresses organized by the College of Dental Surgeons of Costa Rica (CDSCR) and the Academic Congress of Dentistry Faculty of the UCR in 2016. The dentists had to be duly incorporated into the CDSCR, and they completed a self-reported questionnaire for data collection (care was taken to ensure that each applicant answered the survey only once). The surveys were handed out and collected at each of the congress events, which were held all around the country, and were, therefore, a representative sample of all dentists in Costa Rica.

\section{SURVEY INSTRUMENT}

The survey instrument was applied as a physical questionnaire to the participating subjects. It was reviewed and corrected by an allergist, immunologist, and biostatistics specialist. This questionnaire was validated through a pilot study (unpublished data). Informed consent was needed for the formal application of the questionnaire, and was approved by the Scientific Ethics Committee of the UCR (resolution VI-62092014, session N281, September 24, 2014). The questionnaire was registered at the Vice-Rectory of Research of the UCR, under the code 440-B5376. The CDSCR granted the approval and assistance permit to collect the necessary information of dentists at different academic congresses that were carried out in 2016. All participating subjects consented to participate. 
The questionnaire collected data such as demographic information, history of exposure to dental environments and dental materials, familial and personal history of allergic disorders, and descriptions of allergic manifestations to foods, medicines, and dental materials.

\section{STATISTICAL ANALYSES}

A descriptive cross-sectional study with inferential analysis was carried out based on surveys conducted in 2016 of dentists. The prevalence of allergies to different materials, medications, and foods was evaluated.

The statistical methods used were the crossing of variables, frequency distributions, and comparison of the means based on the analysis of variance (ANOVA). The statistical analysis was carried out using the Statistical Package for the Social Sciences version 13.0 and Microsoft Excel. An ANOVA was used to test the following hypothesis:

- HO: The averages in the populations are equal.

- H1: At least one of the averages is different.

Since there were two distributions of nominal and ordinal variables, the homogeneity test of the Kolmogorov Smirnov statistic was performed. This tests whether two groups come from populations with the same distribution. The Student's t-test was used to test for $95 \%$ confidence in the following hypothesis of the difference in the averages:

- HO: The difference in the percentage of prevalence in atopy is equal to 0 .

- H1: The difference is different from 0 .

\section{RESULTS}

A cross-sectional study was performed on 664 out of the 5,223 dentists incorporated in the CDSCR. The average age of the dentists was 37.5 years $(95 \% \mathrm{Cl})$, ranging from 20 to 78 years, with a median age of 35 years. No statistically significant difference was found between the mean ages of males and females (39 and 36.8 years, respectively) (Table 1).

Depending on which university the dentists attended, there was a statistically significant difference regarding age $(p=0.0001)$. Dentists who graduated from the UCR had a higher average age than all the other university graduates (see Table 2).

The average time of exposure to the dentistry environment was determined as 16 years $(95 \% \mathrm{Cl})$. When compared, age and time of exposure to dentistry-related environments had a high and positive correlation of $0.742(p=0.0001)$, indicating that as age increases, so does the time of exposure.

About a third of the dentists (36\%) reported having a chronic illness, with dyslipidemia being the most common, followed by arterial hypertension, and obesity (Figure 1). If the dentists were younger than 35 years, there was a 30\% prevalence of some chronic illness, while those older than 35 years had a $45 \%$ prevalence of illness; this difference was statistically significant $(p=0.0001)$.

Dentists reported having a history of allergies before studying dentistry in $39 \%$ of cases, a prevalence of $42 \%$ in females and $32 \%$ in males. This difference was statistically significant $(p=0.01)$. The most common allergic reactions reported were rhinitis $(25.9 \%)$, dermatologic manifestation $(20.9 \%)$, and asthma (10.1\%). Almost two-thirds $(61 \%)$ of the dentists surveyed reported having first-degree relatives who had presented some type of allergic reaction, with rhinitis being the most common (Figure 2 and Figure 3). These two factors, a history of prior allergies, and familial allergy history, had a low yet positive correlation 
with the development of allergies to food, medicines, and dental materials (Table 3 ).

The dentists surveyed reported a prevalence of $20.9 \%$ for food allergies, $14 \%$ in males, and $24 \%$ in females. This difference was statistically significant $(p=0.005)$. The types of foods that produced the greatest number of allergic manifestations were lactose, shrimps, tomatoes, and pineapples. Gastrointestinal manifestations were more prevalent when associated with lactose, but the other foods mentioned primarily caused an allergic dermatitis reaction. All manifestations appeared within the first 120 min of food ingestion.

Medication allergies were reported by $19 \%$ of dentists. Penicillin and nonsteroidal anti-inflam- matory drugs (NSAIDs) were reported to be more likely to induce allergic reactions. Female dentists had a $21 \%$ prevalence of medication allergies, whereas males reported only a $14 \%$ prevalence, resulting in a statistically significant difference $(p=0.03)$. The reactions reported always occurred within the first 120 min of exposure, with the most common being dermatologic manifestations.

Allergies to dental materials were reported in $26 \%$ of dentists, with a statistically significant difference by sex $(p=0.0001)$, with a $16 \%$ prevalence in males and $31 \%$ prevalence in females. Most allergic reactions were caused by latex and acrylics. Dermatitis was the most common manifestation reported, always within the first 120 min of exposure.

Table 1. Group distribution according to sex and age between Dentists in Costa Rica 2016.

\begin{tabular}{|c|c|c|c|c|c|c|}
\hline \multirow{3}{*}{$\begin{array}{l}\text { Quinquennial } \\
\text { age groupsq }\end{array}$} & \multicolumn{4}{|c|}{ Sex } & \multirow{2}{*}{\multicolumn{2}{|c|}{ Total }} \\
\hline & \multicolumn{2}{|c|}{ Women } & \multicolumn{2}{|c|}{ Male } & & \\
\hline & $\#$ & $\%$ & $\#$ & $\%$ & $\#$ & $\%$ \\
\hline $20-24$ & 20 & 4.4 & 9 & 4.4 & 29 & 4.4 \\
\hline $25-29$ & 91 & 20 & 39 & 19.2 & 130 & 19.7 \\
\hline $30-34$ & 112 & 24.6 & 40 & 19.7 & 152 & 23.1 \\
\hline $35-39$ & 100 & 21.9 & 46 & 22.7 & 146 & 22.2 \\
\hline $40-44$ & 50 & 11 & 19 & 9.4 & 69 & 10.5 \\
\hline $45-49$ & 23 & 5 & 10 & 4.9 & 33 & 5 \\
\hline $50-54$ & 20 & 4.4 & 9 & 4.4 & 29 & 4.4 \\
\hline $55-59$ & 20 & 4.4 & 11 & 5.4 & 31 & 4.7 \\
\hline $60-64$ & 14 & 3.1 & 12 & 5.9 & 26 & 3.9 \\
\hline $65+$ & 6 & 1.3 & 8 & 3.9 & 14 & 2.1 \\
\hline Total & 456 & 100 & 203 & 100 & 659 & 100 \\
\hline
\end{tabular}

Source: Survey instrument applied to dentist cohort in 2016. 
Table 2. Mean graduation age from different universities between Dentists in Costa Rica.

\begin{tabular}{cccc}
\hline University & Average age (years) & N & Standard deviation \\
\hline UCR & 41.3 & 343 & 12.1 \\
Latina & 32 & 144 & 6.1 \\
Ulacit & 32.6 & 109 & 5.7 \\
Veritas FACO & 35.8 & 37 & 6.5 \\
Foreign & 49.1 & 9 & 11.1 \\
UIA & 35.2 & 16 & 3.1 \\
Total & 37.5 & 658 & 10.7 \\
\hline
\end{tabular}

Source: Survey instrument applied to dentist cohort in 2016.

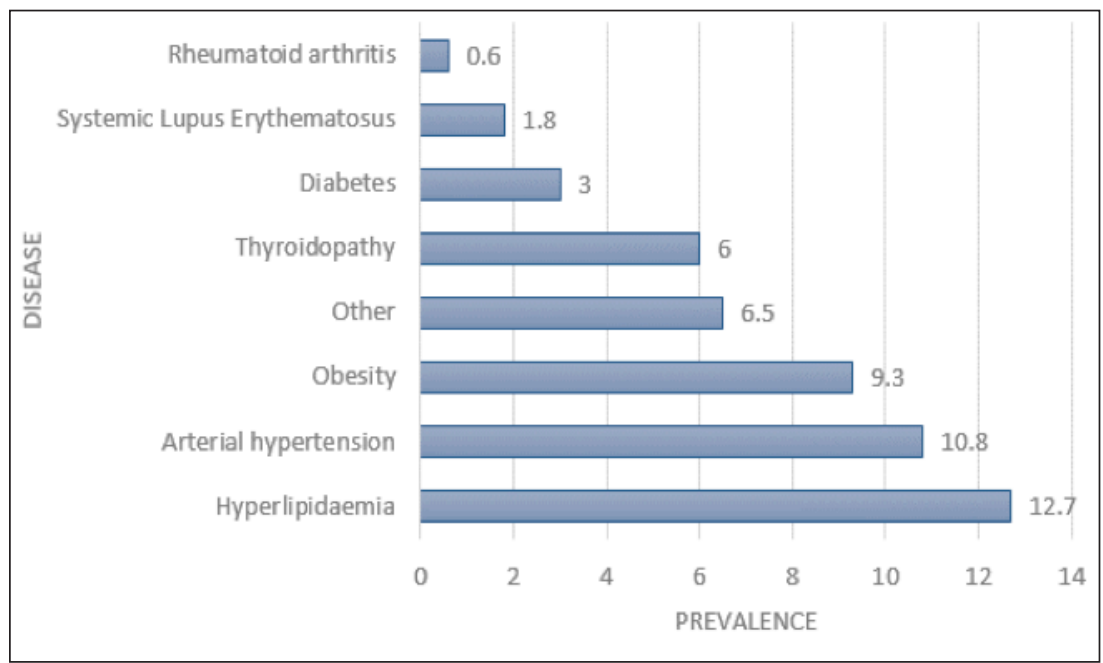

Source: Survey instrument applied to dentist cohort in 2016.

Figure 1. Chronic disease prevalence between Dentists in Costa Rica 2016.

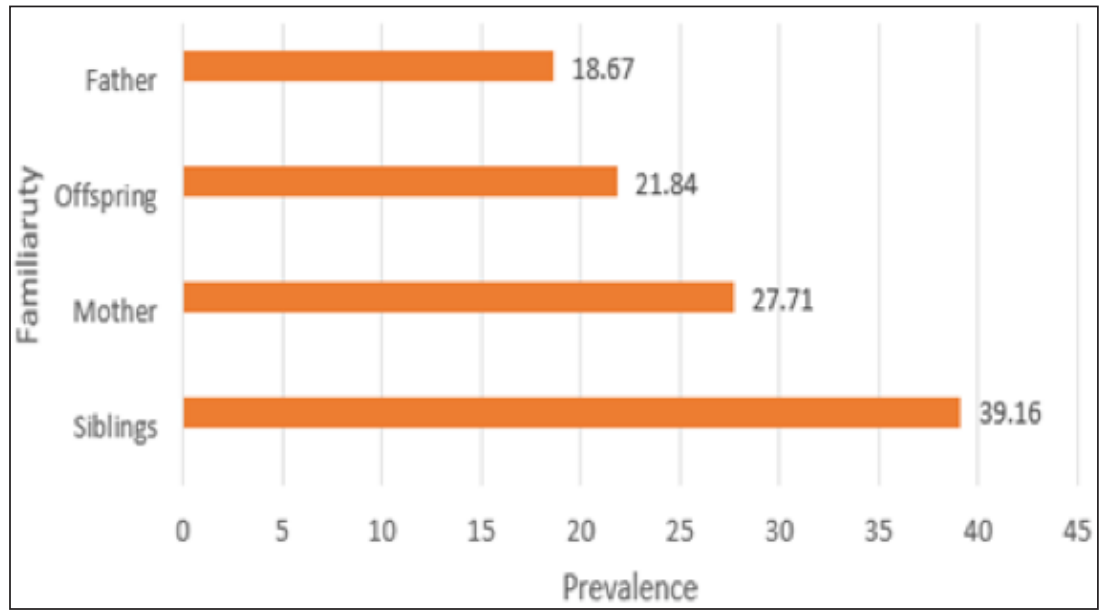

Source: Survey instrument applied to dentist cohort in 2016.

Figure 2. Prior allergic reaction prevalence of family members of Dentists in Costa Rica 2016. 


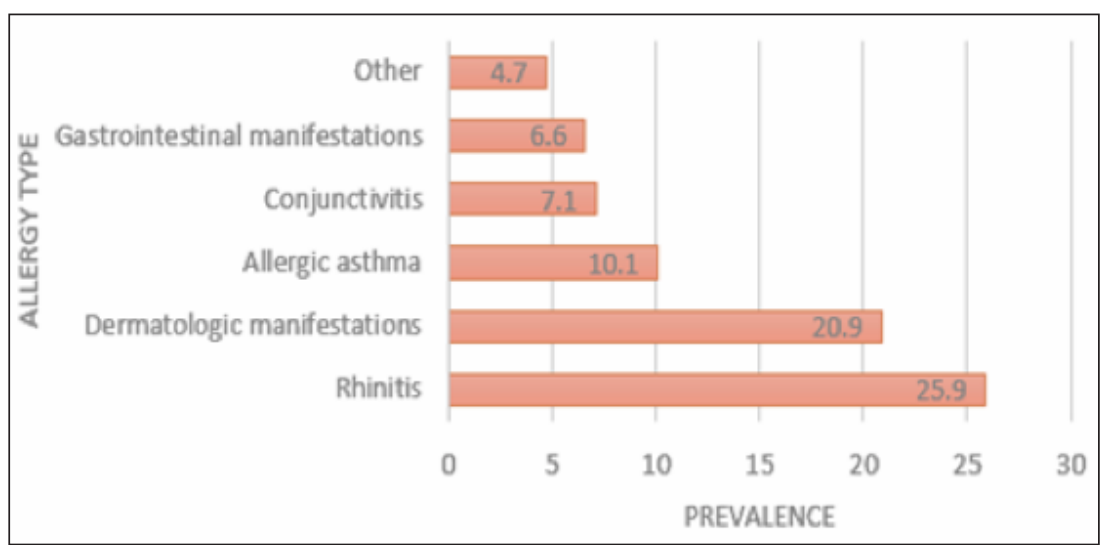

Source: Survey instrument applied to dentist cohort in 2016.

Figure 3. Allergic reaction prevalence prior to dental studies between Dentists in Costa Rica 2016.

Table 3. Correlation of allergy prevalence between Dentists in Costa Rica 2016.

\begin{tabular}{|c|c|c|c|c|c|c|c|}
\hline & & $\begin{array}{l}\text { Prior } \\
\text { allergy }\end{array}$ & Food & Drugs & $\begin{array}{c}\text { Dental } \\
\text { materials }\end{array}$ & $\begin{array}{l}\text { Chronic } \\
\text { Illness }\end{array}$ & $\begin{array}{l}\text { Allergic } \\
\text { familial } \\
\text { history }\end{array}$ \\
\hline \multirow[t]{3}{*}{ Prior allergy } & Bilateral significance & 1 & 0.310 & 0.241 & 0.259 & -0.004 & $*_{-}$ \\
\hline & correlation & & 0 & 0 & 0 & $0-916$ & *- \\
\hline & N & 664 & 657 & 662 & 664 & 664 & ${ }^{*}-$ \\
\hline \multirow[t]{3}{*}{ Food } & Bilateral significance & 0.310 & 1 & 0.243 & 0.255 & 0.073 & 0.163 \\
\hline & correlation & 0 & & 0 & 0 & 0.061 & 0 \\
\hline & N & 657 & 657 & 657 & 657 & 657 & 657 \\
\hline \multirow[t]{3}{*}{ Drugs } & Bilateral significance & 0.241 & 0.243 & 1 & 0.096 & 0.141 & 0.000 \\
\hline & correlation & 0 & & & 0.014 & 0 & 0.176 \\
\hline & N & 662 & 657 & 662 & 662 & 662 & 0 \\
\hline \multirow{3}{*}{$\begin{array}{c}\text { Dental } \\
\text { materials }\end{array}$} & Bilateral significance & 0.259 & 0.255 & 0.096 & 1 & 0.016 & 0.133 \\
\hline & correlation & 0 & 0 & 0.014 & & 0.685 & 0 \\
\hline & N & 664 & 657 & 662 & 664 & 664 & 664 \\
\hline \multirow[t]{3}{*}{ Chronic IIIness } & Bilateral significance & -0.004 & 0.073 & 0.141 & 0.016 & 1 & *- \\
\hline & correlation & 0.916 & 0.061 & 0 & 0.685 & & $*_{-}$ \\
\hline & N & 664 & 657 & 662 & 662 & 664 & *- \\
\hline \multirow{3}{*}{$\begin{array}{c}\text { Allergic } \\
\text { familial history }\end{array}$} & Bilateral significance & *- & 0.163 & 0.176 & 0.133 & *- & 1 \\
\hline & correlation & *- & 0 & 0 & 0 & *- & \\
\hline & N & *- & 657 & 662 & 664 & *- & 664 \\
\hline
\end{tabular}

Source: Survey instrument applied to dentist cohort in 2016. 


\section{DISCUSSION}

This study aimed to determine the prevalence and type of allergies in Costa Rican dentists. Data was collected regarding allergic reactions associated with food, drugs, and dental materials and analyzed, taking into account the hereditary factors and associated systemic conditions that may influence an immune response.

The immune system can recognize the body's own cells, as well as pathogens and toxins, once it has been exposed to them. Moreover, it can defend against these external aggressions, meaning re-exposure will elicit an immune response $(2,35)$.

Immune responses can be classified as innate and acquired (8,35-37), depending on the type of reactions triggered (2,8,36-39). Innate responses are immediate but nonspecific reactions, meaning that the same mechanism is used against all pathogens (5,36-40). Acquired responses involve a different unique reaction to each pathogen. However, these are not immediate, in contrast to innate reactions, which are immediate $(2,5,8,36,39-40)$. The acquired immune system has four specific characteristics: antigenic specificity, antigenic diversity, immunologic memory, and the ability to recognize what is exogenous $(5,36$, 39-40). Antigens are molecules that stimulate the immune system to generate antibodies or initiate a cell-mediated response (5). Antibodies, also known as immunoglobulins $(\mathrm{lg})$, are produced by mature B lymphocytes (plasma cells). Antibodies bind antigens for protection against pathogens, and there are five types: $\lg A, \lg D, \lg E, \lg G$, and $\lg M(5)$.

Hypersensitivity reactions can be classified depending on the cells and the chemical mediators involved, as well as the delay and severity of the reaction. Type I hypersensitivity is a fast reaction mediated by TH2-lymphocytes, $\operatorname{lgE}$, and mast cells, which leads to the release of pro-inflammatory cytokines $(6,14,45-46)$. It occurs a few minutes after the binding of the antigen to an antibody in patients previously sensitized to the antigen $(14,45,47-48)$. The immediate hypersensitivity of type I is a systemic response to residual proteins, a reaction classified as an allergy $(14,45)$. This type of hypersensitivity can occur as a systemic or localized reaction $(6,37)$. Local reactions differ depending on the entry point of the allergen, localized skin swelling, nasal and conjunctival secretions, and asthma $(6,37)$. Anaphylaxis is a systemic reaction caused by the release of histamine and other mediators (48-49). It has a sudden onset and lasts less than $24 \mathrm{~h}$, producing life-threatening symptoms such as laryngeal edema, angioedema, obstruction of the lower airway, hypotension or circulatory collapse, vomiting, diarrhea, and urticari $(14,48-51)$.

A type I hypersensitivity reaction has two well-defined phases: an early-stage that presents vasodilation that increases vascular permeability and smooth muscle spasm or glandular secretion, and a delayed reaction that occurs without additional exposure to the allergen and where eosinophils, neutrophils, basophils, mast cells, and lymphocytes infiltrate the tissue, causing destruction $(7,37,47-48,52)$. The early-stage symptoms are observed between 5 and 30 min (up to 1-2 h) after antigen exposure, and they tend to disappear after $60 \mathrm{~min}$. In contrast, the delayed phase begins within 2-4 $\mathrm{h}$ and lasts up to $24 \mathrm{~h}$, lasting up to several days $(6,37,48,53)$. Patients with these characteristics have more elevated serum levels of IgE and IL-4 producing TH2-lymphocytes than the general population and a positive family history of allergy (37). Typical examples of type I hypersensitivity include asthma, rhinitis, anaphylaxis, some types of dermatitis and conjunctivitis, gastrointestinal reactions, latex allergy, food allergies, and drug allergies (14-17). 
Atopy refers to the genetically and environmentally determined predisposition to develop clinically expressed disorders, including allergic rhinitis, atopic dermatitis, eczema, and allergic asthma, regulated through immune phenomena in which many cells (i.e., mast cells, eosinophils, and T lymphocytes) and associated cytokines, chemokines, and neuropeptides play a role (58). Atopy is considered a hereditary condition that predisposes a patient to series of IgE-mediated responses and alterations in cellular immunity and vascular reactivity (59-60). The surveyed dentists indicated that 39\% had allergies prior to dental school, with a statistically significant difference by sex $(p=0.01)$. This can be considered high compared to what Torres Fernan (60) reported in his study, that is, 10 to $15 \%$ of the world population suffered from an allergic disease. The results obtained in this investigation share the same behavior as described by Risenga et al. and Thong et al., where females have a higher prevalence of allergic reactions than males $(61,62)$. According to $\mathrm{Ngo}$ et al., this is because females have greater humoral and cellular activities in immune reactions than males (63).

Some factors increase the risk of developing an allergic reaction, such as gender, tobacco smoke, poor hygiene, familial or personal history of allergies, respiratory viral infections, some endotoxins, pets, environmental pollutants, and indoor or outdoor allergens $(25-34,64)$. Several prospective studies have confirmed that obesity is a risk factor for asthma or allergic disease. Many of these studies also considered the dietary factors and level of physical activity, demonstrating that asthma is specifically associated with obesity and not with a lack of physical activity or type of diet $(30,38-41,48-51,64)$. Patients with obesity have a higher prevalence of asthma, thus having an increased risk of having exacerbated inflammatory reactions $(41,48-51,64)$. More than a third $(36 \%)$ of the dentists interviewed suffered from a chronic disease. The most reported chronic diseases were dyslipidemia and obesity, which tended to appear more frequently as age increased. In an investigation conducted in Canada, Chen et al. also reported that obesity affects the occurrence of allergies. They found that adipokines and cytokines secreted by the adipose system intervene in the immune response, decreasing tolerance to different agents that may attack the body $(48,65)$.

In a study of 3,327 children aged 2-14 years carried out in Wuhan, China, obesity increased the prevalence of allergic rhinitis and atopic dermatitis, especially in girls, suggesting a difference depending on weight and sex (64). In this study, a low positive correlation was found between having a chronic illness and developing food allergies $(r=0.073)$, medication allergies $(r=0.141)$, and allergies related to dental materials $(r=0.016)$.

A history of family allergies is an important risk factor for the predisposition of allergic reactions (7). Approximately $12-15 \%$ of the general population is at risk of suffering from an allergic disease. In contrast, there is a $19 \%$ risk of having an allergic reaction if a parent suffers from some type of allergy. If both parents are atopic, their offspring's risk is $19 \%-42 \%$, whereas if both parents have the same allergic disease, the risk increases to $42 \%-72 \%(17,36,66)$. A statistically significant positive correlation was observed between the allergic antecedents prior to starting dental school and having relatives with a history of atopy $(61 \%)$. One study managed to relate the R576 allele with greater IgE values in patients with relatives with atopy (67). Gershwin et al. mentioned an increase in the predisposition of allergic disease when there is a personal and family history of allergies (19). In an analysis conducted by Cooke and Van der Veer, cited by Zubeldia (43), 504 individuals with allergic disease were compared with 76 non-allergic controls. They found that half of the people with allergies had a family history of allergies, while in the second group, only $14 \%$ had such a family history. All of the above findings 
are in agreement with our study results, where the prevalence of allergy in a first-degree relative has a low and positive correlation that is statistically significant with the development of allergies.

Drugs can cause type I reactions (mediated by $\lg \mathrm{E}$ ) and type IV reactions (mediated by $\mathrm{T}$ cells) (62,68-69). The immediate reactions are more related to antibiotics and NSAIDs, which can result in urticaria, angioedema, bronchospasm, or even cardiovascular collapse. In contrast, delayed reactions are more related to anticonvulsants, sulphas, and some medications for AIDS treatment (19-22,68-69). Medication-related allergies were also reported by some dentists, particularly to penicillin and NSAIDs. Beta-lactam antibiotics are the main cause of medication-related allergic reactions, followed by NSAIDs. There is no clear reason why some medications cause more allergies than others, which may be related to the frequency of use in the general population (43). According to Zubeldia (43), Gómez (70), and Yang (36), beta-lactam antibiotics are the main cause of allergic reactions to medications (approximately $50 \%$ of cases), followed by NSAIDs, which represent $39 \%$ of reactions (43). The incidence of allergy to penicillin in the general population is $1-10 \%$ (43), while the prevalence ranges between $10-12 \%(71-74)$. This study found a significant difference by sex $(p=0.03)$ in cases of penicillin allergy reported in dentists, with a higher prevalence of cases in females (21\%) than in males (14\%); Albin et al. (72) found that females were associated with a higher rate of reported allergy cases, although Ponvert et al. (74) postulates that age, sex, and personal history of atopy are not significant risk factors for developing hypersensitivity to beta-lactam antibiotics.

About $26 \%$ of dentists in this study reported having an allergic reaction to dental materials. Dermatitis was the most frequent, and even more so when associated with the use of latex gloves. Globally, the prevalence of latex allergy in the general population has been reported to range between 6-12\%, while in health professionals, it can range between 3-22\% (75-83). According to Amasekera et al. and others, the time in contact with different dental materials is a risk factor for developing allergies to these materials (84-91). The more dentists come into contact with materials, the higher the probability of sensitization and, therefore, the higher the likelihood that an allergic reaction will occur. Ahmed et al. (92) claimed that frequent exposure to latex products is significantly correlated with a higher prevalence of allergy to latex gloves in health workers. According to Boyce et al., other materials such as acrylic generate a localized immune response that is almost always limited to the contact area of the skin (93). The possibility of contact dermatitis that is not mediated by $\lg E$ should always be considered. It is often believed that the allergic reactions that health workers have are, in general, due to latex. Specific tests such as patch testing must be carried out, given that the allergen could be due to another reason (88). Mikov et al. (89) showed that not all reactions are due to latex, but in some cases, acrylate macromolecules can cross through latex, resulting in an allergic reaction. The reaction to acrylics is due to direct contact with the skin or mucosa and is attributed mostly to the non-polymerized monomers in these materials (94-95). The monomers can cause clinical cases of dermatitis and even neuropathies in the fingers or hands $(56,59)$.

Pimentel (86) indicated that dentists are a population at risk of developing allergies due to frequent contact with dental materials that can trigger type I hypersensitivity reactions mediated by $\lg \mathrm{E}$. Some studies showed that $40 \%$ of individuals with sensitivity to latex also have sensitization to different types of fruit. This cross-reactivity is known as latex-fruit syndrome (96-97). The main types of fruit related to this type of allergic reaction are bananas, avocados, kiwifruit, grapes, passionfruit, pineapples, peaches, papayas, 
walnuts, tomatoes, and cherries (65,96-102). It is characterized by an immediate hypersensitivity reaction to two different allergenic sources: latex and fruit. The main allergens responsible for this cross-reaction are Hev b5, Hev b6, and Hev b7, which are proteins related to the protection system of the latex plant (Hevea brasiliensis) and are also contained in avocados, papayas, pineapples, tomatoes, and other vegetables $(98,102-104)$.

In this study, a low but positive correlation for dentists was found between allergy to dental materials and foods $(r=0.255)$. About a fifth $(20.9 \%)$ of the dentist population reported some type of food allergy, whereas the prevalence of food allergies varies from $2 \%$ to $8 \%$ in the general population (66). Females reported having the most allergic manifestations. According to the Spanish Society of Allergology and Clinical Immunology 2005 , the foods that result in an allergic reaction most frequently are fruit, nuts, seafood, eggs, and milk (105). Similarly, dentists reported that lactose, shrimps, pineapples, and tomatoes caused the most allergic reactions. The most common allergic reaction was urticaria. Furthermore, Scurlock and Burks mentioned that urticaria is probably the most common reaction (106).

There seems to be an increase in the number of allergic reactions to food, medications, and dentistry-related materials. This could be associated with increased antigenic exposures in dental environments and cross-reactivities or repeated exposures to medication, as advocated by Baldo and Pham in 2013 (69). These findings may be helpful for developing improved health policies for dental professionals. Future research should include a larger population sample.

\section{CONCLUSIONS}

In conclusion, there is a directly proportional relationship between age, time of exposure to dental environments, and the risk of developing allergic conditions to dental materials $(26 \%$ in this study). A low and positive correlation was observed between the presence of a chronic illness and the predisposition to develop an allergic reaction to food, medicines, and dental materials. There was a low and positive correlation between the presence of allergies in a first-degree relative and the prevalence of allergies between dentists. There was a low and positive correlation between the development of allergies to dental materials and allergies produced by the intake of some foods such as pineapples, tomatoes, and seafood. The main adverse reactions reported in dentists due to exposure to dental materials, medicines, and/or food were gastrointestinal, skin, and respiratory problems.

\section{CONFLICTS OF INTEREST}

The authors declare no conflict of interest in this article and it is the authors' original work.

\section{ACKNOWLEDGEMENTS}

Dr. Olman Riggioni Cordero, MSc. Jacqueline Castillo-Rivas, Colegio de Cirujanos Dentistas de Costa Rica, Facultad de Odontología-Universidad de Costa Rica.

\section{REFERENCIAS}

1. Covar R.A., Fleischer D.M., Cho C., Boguniewicz M. (2013) Allergic Disorders. 
In: Current, Diagnosis \& Treatment: Pediatrics, 22nd edn. McGraw-Hill, USA pp 1171-1206.

2. Sánchez S., Butnaru D. (2013) Modelos de reconocimiento inmunológico: Tolerancia e inmunidad en el marco de la evolución del conocimiento científico. Inmunología 32 (4): 139-147.

3. Pichler W., Naisbitt D., Park K. (2011) Immune pathomechanism of drug hypersensitivity reactions. Journal Allergy Clinical Immunology 127: 74.

4. Shizuo A., Satoshi U., Osamu T. (2006) Pathogen recognition and innate immunity. Cell 124: 783-801.

5. Janson L., Tischler M. (2012) The Big Picture: Medical Biochemistry. McGrawHill, New York.

6. Levinson W. (2014) Review of Medical Microbiology and Immunology. 13ed McGraw-Hill, New York.

7. Canteros G. (2007) Reacciones de hipersensibilidad. Revista de Posgrado de la VIa Cátedra de Medicina 167:11-16.

8. Butnaru D., Sánchez-Ramón S. (2013) Modelos de reconocimiento inmunológico: tolerancia e inmunidad en el marco de la evolución del conocimiento científico. Inmunología. 32: 139-147.

9. Toche P. (2012) Visión panorámica del sistema inmune. Revista Médica Clínica Las Condes.23: 446-57.

10. Kishiyama J.L. (2013) CURRENT Diagnosis \& Treatment: Occupational \& Environmental Medicine. 5e. McGraw-Hill, New York.

11. Robbins L., Cotran S., Kumar A., Aster F. (2010) Patología Estructural y Funcional. 8e. Elsevier, España.

12. Akdis C., Sugita K., Morita H., Kubo T. (2017) Introduction to Mechanisms of Allergic Diseases. Middleton's Allergy Essentials. 1: 127 .

13. Longo D., Kasper D., Jameson L., Fauci A., Hauser S., Loscalzo J. Harrison (2012)
Principios de Medicina Interna. 18e. Mc Graw Hill, USA.

14. Kindt T., Goldsby R., Osborne B. (2007) Inmunología de Kuby. McGrawHill, México.

15. Díaz D., Prieto A., Úbeda M., Álvarez M. (2013) Linfocitos T Medicine. 11 (28): 1699-709.

16. Lomonte B. (2009) Nociones de Inmunología. Universidad de Costa Rica http://www.kerwa.ucr.ac.cr/bitstream/ handle/10669/9238/Nociones_Inmunologia web.pdf? sequence $=1 \&$ isAllowed $=y \quad$ Accessed April 20, 2018.

17. Escobar M. (2012) Type I hypersensitivity to the house dust mites: Immune mechanisms and diagnosis. Medicina y Laboratorio 18: 518.

18. Becker E. (2013) Drug allergies and implications for dental practice. Anesth Prog 60: 188-197.

19. Gershwin E., Naguwa S. (2006) Alergia e Inmunología: Secretos. 2e. Elsevier, España.

20. Fireman P. (2007) Atlas de Alergia e Inmunología Clínica. 3e Elsevier, España.

21. Arriba S., Muñoz C., Lorente F. (2008) Alergia a medicamentos. An Pediatr Contin 6 (1): 12-9.

22. Khan D., Solensky R. (2010) Drug allergy J. Allergy Clin Immunol 125 (2): S126-37.

23. Rabinovich G. (2004) Inmunopatología molecular: nuevas fronteras de la medicina: un nexo entre la investigación biomédica y la práctica clínica. Editorial Médica Panamericama, Buenos Aires.

24. Ferastraoaru D., Ramesh M., Rosenstreich D. (2015) Immunological Hypersensitivity Reactions. In: Rosenstreich D (ed), Manual of Allergy and Clinical Immunology for Otolaryngologists, 1st edn. Plural Publishing Inc, California pp 29-62.

25. Mota A., Nair B., Turrini R.N. (2012) Hipersensibilidad al látex en el perioperatorio: Una revisión integradora de la literatura. Revista Latino-Americana de Enfermagem 20 (2): 411-420. 
26. A Richmonds S., Popat H., Toma A., Player R., Henderson J., et al. (2014) A three- dimensional analysis of the effect of atopy on face shape. European Journal of orthodontics 36 (5): 506-511.

27. Peñarrubia García P. (2003) Alergias. Inmunología on line. https://issuu.com/ laboratorio_hu/docs/alergias Accessed 26 June 2018

28. Talesnik E., Hoyos R. (2006) Nueva nomenclatura de las enfermedades alérgicas $\mathrm{Su}$ aplicación pediátrica. Revista Chilena de Pediatría. 77 (3): 239-246.

29. Weidinger S., Rummler L., Klopp N., Wagenpfeil S., Baurecht H. (2005) Association study of mast cell chymase polymorphisms with atopy. Allergy 60:1256-1261.

30. Scott H., Sicherer M.D., Donald Y., Leung M.D. (2005) Advances in allergic skin disease, anaphylaxis, and hypersensitivity reactions to foods, drugs, and insects. J Allergy Clin Immunol. Food allergy, dermatologic diseases and anaphylaxis. 116 (1).

31. Weston W., Howe W. (2017) Overview of dermatitis. UpToDate https://www. uptodate.com/contents/overview-of-dermatitis-eczema? search=overview $\% 20$ of $\% 20$ dermatitis\&source $=$ search $\_$result\&selected Title $=1 \sim 150 \&$ usage_type $=$ default\&display_ rank=1 Accesed 20 May, 2018

32. Van Arsdel P. (1994) Trastornos por hipersensibilidad. El Manual Merck 9th ed. Doyma libros S.A., España.

33. Murano A. (2015) Oral immunotherapy in food allergy: Present and future. Anales de Pediatría (English Edition). 82 (4): 213-215.

34. Mendoza M., Vargas M., Guillén J., Moncada A., Navarro B., Sienra J. (2007) Anafilaxia y choque anafiláctico. Revista Alergia México 54: 34-40.

35. Cabanillas J., Sánchez L. (2012) Atopic dermatitis. Dermatol Perú 22: 176.
36. Yang F., Luo X., Xing Q., Yang Y., Zhu Q., Meng C., Ma, L. Sun X., Xu J. (2015) Research on Susceptible Genes and Immunological Pathogenesis of Cutaneous Adverse Drug Reactions in Chinese Hans. Journal of Investigative Dermatology Symposium Proceedings 17 (1): 29-31.

37. Antolín D., Rodríguez M., Barbarroja J., Sánchez M. (2013) Reacciones alérgicas a alimentos. Medicine 11 (29): 1788-96.

38. Méndez de Inocencio J., Huerta J., Bellanti J., Ovilla R., Escobar A. (2008) Alergia: Enfermedad multisistémica. Fundamentos básicos y clínicos. Editorial Médica Panamericana, México.

39. Cortés X., Soriano J., Sunyer J., Martínez J., Muniozgoren N., Maldonado J., Quirós R., Antó J. (2000) Factores asociados al desarrollo de atopia en adultos jóvenes. Medicina clínica 114 (5): 165-168.

40. Ramírez del Pozo M., Gómez-Vera J., LópezTiro J. (2012) Factores de riesgo asociados al desarrollo de marcha atópica: Estudio de casos y controles. Revista Alergia México 59 (4): 199-203.

41. Vega-Robledo G., Valencia-Zavala M., Sánchez-Olivas M. (2012) Asociación de obesidad y asma alérgica en adultos. Revista alergias en México 59 (4): 173-179.

42. Du Toit G., Foong R., Lack G. (2016) Prevention of food allergy - early dietary interventions. Allergology International 65 (Aug): 370-377.

43. Zubeldia J., Baeza M., Jáuregui I., Senent C. (2012) Libro de las enfermedades alérgicas de la Fundación BBVA. 1a ed Fundación BBVA, Bilbao.

44. Bellanti J. (2008) Alergia: Enfermedad Multisistémica, Editorial Panamericana, Argentina.

45. Cunha Souza da S., Lima Barreto M., Leovigildo Fiaccone R., et al. (2010) Asthma cases 
in childhood attributed to atopy in tropical area in Brazil. Revista Panamericana de Salud Pública. 28 (6): 405-411.

46. Baldacara R., Fernandes M., Baldacara L., Aun W., Mello J., et al. (2013) Prevalence of allergen sensitization, most important allergens and factors associated with atopy in children. Sao Paulo Medical Journal. 131 (5): 301-308.

47. Adisesh A., Robinson E., Nicholson P., Sen D., Wilkinson M. (2013) U.K. standards of care for occupational contact dermatitis and occupational contact urticaria. British Journal of Dermatology http://doi.org/10.1111/ bjd. 12256

48. Chen Y., Rennie D., Cormier Y., Dosman J. (2010) Association between Obesity and Atopy in Adults. International Archives of Allergy and Immunology. 153 (4): 372-377.

49. Fitzpatrick S., Joks S., Silverberg I. (2011) Obesity is associated with increased asthma severity and exacerbations and increased serum immunoglobulin $\mathrm{E}$ in inner-city adults. Clinical Et Experimental Allergy 42 (5): 747-759.

50. Hersoug L., Linneberg A. (2007) The link between the epidemics of obesity and allergic diseases: does obesity induce decreased immune tolerance? Allergy 62 (10): 1205-1213.

51. Story R.E. (2007) Asthma and obesity in children. Current opinion in paediatrics 19 (6): 680-684.

52. Carrol K.C., Hobden J.A., Miller S., Morse S.A., Mietzner T.A., Detrick B., Mitchel T.G., Mckerrow J.H., Sakanari J.A. (2016) Jawetz, Melnick \& Adelberg's Medical Microbiology 27th edn McGraw-Hill, New York.

53. Restrepo D., Ardila C. (2010) Reacciones adversas ocasionadas por los biomateriales usados en prostodoncia. Avances en odontoestomatología 26 (1): 19-30.

54. Wrangsjo K., Boman A., Lidén C., Meding B. (2011) Primary prevention of latex allergy in healthcare-spectrum of strategies including the European glove standardization. Contact Dermatitis 66: 165-171.

55. Lypiana Maya, et al. (2014) Concomitant contact allergy to formaldehyde and methacrylic monomers in students of dental medicine and dental patients. International Journal of Occupational Medicine and Environmental Health 21 (5): 797-807.

56. Strazzula L., Das S., Nambudiri V., Kroshinsky D. (2014) Fingertip purpura in a dental student: an unusual manifestation of methyl methacrylate dermatitis. JAMA Dermatology https:// doi.org/10.1001/jamadermatol.2013.8520

57. Khan A., Siddiqui A., Askari, H., Imtiaz, F., Shakoor, S. (2014) Dental composite related allergic reactions in dentists working in Karachi. Pakistan Oral and Dental Journal 34 (2); 382-386.

58. Hamann C., Rodgers P.A., Sullivan K. (2003) Allergic contact dermatitis in dental professionals: effective diagnosis and treatment. The Journal of the American Dental Association 134 (2): 185-194.

59. Schiaffino M. (2007) Interacción de productos médicos con la piel normal. Dissertation, Universidad Nacional de La Plata https://docplayer.es/6336454-Interaccionde-productos-medicos-con-la-piel-normal. html\#show_full_text Accessed 20 May 2018

60. Torres Fermán I., Vazquez Nava F., Beltrán Guzmán F., Ochoa D., Barrientos Gómez Ma. (2012) Alergias, asma, rinitis y eczema en niños y su relación con la lactancia, dieta y uso de medicamentos. Revista Electrónica Medicina, Salud y Sociedad 2 (2).

61. Risenga S., Shivambu G., Rakgole M., Makwela M., Ntuli S., Maligavhada N., et al (2013) Latex allergy and its clinical features among healthcare workers at Mankweng Hospital, Limpopo Province, South Africa. South Africa Medicine Journal 103 (6): 390-394 https://www.ncbi.nlm.nih.gov/ pubmed/23725958 
62. Thong B., Choon T. (2011) Epidemiology and risk factors for drug allergy. BJCP 71 (5): 684-700.

63. Ngo S., Steyn F., McCombe P. (2014) Gender differences in autoimmune disease. Frontier in Neuroendocrinology 35: (347-369).

64. Lei Y., Yang H., Zhen L. (2016) Obesity is a risk factor for allergic rhinitis in children of Wuhan (China). Asia Pac Allergy 6 (2): 101.

65. Waserman S., Watson W. (2011) Food Allergy. Practical guide for allergy and immunology in Canada https://doi.org/10.1186/17101492-7-S1-S7

66. Rodríguez P., Muñoz D., Arias A., González S., Herrera D., Vidaurri A. (2009) Características epidemiológicas de pacientes con alergia a alimentos atendidos en el Centro Regional de Alergias e Inmunología Clínica de Monterrey. Revista Alergia México 56 (6): 185-191.

67. García M., Dávila I., Moreno E., Laffond E., Lorente F., González R. (2005) El polimorfismo Q576R del gen IL4RA se asocia con valores elevados de IgE total en pacientes con antecedentes familiares de atopia. Medicina Clínica 124 (6): 211-212.

68. Canto M., Torres M. (2009) Urticaria, angioedema, alergia a medicamentos. Medicine 10 (34): 2249-56.

69. Baldo B., Pham N. (2013) Drug Allergy: Clinical Aspects, Diagnosis, Mechanisms, Structure-Activity and Relationships. Springer, New York .

70. Güitron M., Carrillo M. (2010) Reacciones adversas a medicamentos en la boca del adulto mayor. 67 (4): 163-170.

71. Gomez V., Núñez R., Sierra C. (2007) Dermatitis de contacto alérgica en técnica dental. Revista de Asociación Colombiana de Dermatología 15 (4): 303-305.

72. Albin S., Agarwal S. (2014) Prevalence and characteristics of reported penicillin allergy in an urban outpatient adult population. Allergy
Asthma Proceedings 35 (6): 489-494. http:// doi.org/10.2500/aap.2014.35.3791

73. González A., Radojicic C. (2015) Penici1lin allergy: a practical guide for clinicians. Cleveland Clinic Journal of Medicine 82 (5): 295-30.

74. Ponvert C., Perrin Y., Bados-Albiero A., et al (2011) Allergy to beta lactam antibiotics in children: Results of a 20-year study based on clinical history, skin and challenge tests. Pediatr Allergy Immunol 22: 411-418.

75. Agrawal A., Bhatt N., Kk S., Singh K., Chaudhary H., Asawa K. (2010) Prevalence of allergy to latex gloves among dental professionals in Udaipur, Rajasthan, India. Oral Health \& Preventive Dentistry 8 (4): 345-350.

76. Vandenplas O., Raulf M. (2017) Occupational Latex Allergy: The Current State of Affairs. Current Allergy Asthma Rep https:// doi.org/10.1007/s11882-017-0682-5

77. Crippa M., Belleri L., Mistrello G., Carsana T., Neri G., Alessio L. (2003) Prevention of latex allergy among health care workers: Evaluation of the extractable latex protein content in different types of medical gloves. American Journal of Industrial Medicine https://doi.org/10.1002/ajim.10232

78. Brehler R., Kütting B. (2001) Natural rubber latex allergy. Archives of Internal Medicina https://doi.org/Doi10.1136/Oem.59.6.419

79. Tarlo S. (2011) Natural rubber latex allergy and asthma. Curr Opin Pulm Med 7 (1): 27-31 http://www.ncbi.nlm.nih.gov/ pubmed/11140403

80. Kousky C. (2012) Managing the Risk of sensitisation to latex. Dental Nursing 8 (11).

81. Wudy A., Negro C., Adami A., Filon F.L. (2017) Atopic status and latex sensitization in a cohort of 1,628 students of health care faculties. Annals of Allergy, Asthma \& Immunology https://doi.org/10.1016/j. anai.2017.03.002 
82. Hill R. (2003) Update on latex allergy among health care personnel. AORN 78 (3).

83. Amr S., Bollinger M. (2003) Latex Allergy and Occupational Asthma in HealthCare Workers: Adverse Outcomes. Environmental Health Perspectives https://doi.org/10.1289/ ehp.6612.

84. Gil M., Barriga F.J., Pérez J.A. (2007) Alergia al látex en los trabajadores sanitarios (I): Vigilancia de la salud. Medicina y Seguridad del Trabajo 53 (208): 53-61.

85. Amarasekera M., Rathnamalala N., Samaraweera S., Jinadasa M. (2010) Prevalence of latex allergy among healthcare workers. International Journal of Occupational Medicine and Environmental Health 23 (4): 391-396 https://www.ncbi.nlm.nih.gov/ pubmed/21306985

86. Pimentel E., Garmendia J., Salazar E. (2011) Prevalencia de la alergia y de la sensibilización al látex en el estudiante de postgrado de la facultad de odontología de la UCV. Acta Odontológica Venezolana 49 (3): 1-12.

87. Pimentel H., Garmendia J. (2014) Prevalencia del síndrome látex-fruta en el estudiante de posgrado de la facultad de Odontología de la Universidad Central de Venezuela. Acta odontológica Venezolana 49 (3): 1-12.

88. Rai R., Dinakar D., Kurian S., Bindoo Y. (2014) Investigation of contact allergy to dental materials by patch testing. Indian Dermatol Online J 5(3): 282.

89. Mikov I., Turkalj I., Jovanovic M. (2011) Occupational contact allergic dermatitis in dentistry. Vojnosanitetski pregled 68 (6): 523-525.

90. Blanco C., Carillo T., Castillo R., Cuevas M., Quiralte J. (2004) Latex allergy: clinical features and cross-reactivity with fruits 73 (4): 309-314.
91. Pimentel H. (2015) Alergia al Látex en una profesional de la odontología - Presentación de caso clínico. Acta Odontológica Venezolana 1 (53) http://www.actaodontologica. com/ediciones/2015/1/art-8/ Accessed 20 May 2018.

92. Ahmed A., Zia A., Askari H., Imtiaz F., Shakoor S. (2014) Dental composite related allergic reactions in dentists working in karachi. Pakistan Oral \& Dental Journal 34 (2): 382-38.

93. Boyce J., Austen K. (2017) Alergias, anafilaxia y mastocitosis sistémica. In: Kasper D, Fauci A, Hauser S, Longo D, Jameson J, Loscalzo J (eds) Harrison. Principios de Medicina Interna, 19th edn. McGraw-Hill, New York, ch. 376.

94. Ramos L., Cabral R., Gonçalo M. (2014) Allergic contact dermatitis caused by acrylates and methacrylates - A 7-year study. Contact Dermatitis https://doi.org/10.1111/ cod. 12266

95. Minamoto K. (2014) Allergic contact dermatitis from two- component acrylic resin in a manicurist and dental hygienist. Journal of Occupational Health 56: 229-234.

96. Turjanmaa K. (2007) Allergy to natural rubber latex: a growing problem. Ann Med 26: 297-300.

97. Valenta R., Hochwallner H., Linhart B., Pahr S. (2015) Food Allergies: TheBasics. Gastroenterology. http://doi.org/10.1053/j. gastro.2015.02.006

98. Ricci G., Piccinno V., Calamelli E., Giannetti A., Pession A. (2013) Latex-fruitsíndrome in italian children and adolescents with natural rubber latex allergy. International Journal of Immunopathology and Pharmacology http://journals.sagepub.com/doi/ pdf/10.1177/039463201302600129 
99. Pimentel E., Garmendia J. (2013) Síndrome Látex-Fruta y su importancia en odontología. Acta Odontológica Venezolana 51 (1) 1-10.

100. Manrique E., Celis H.M., Sánchez C.M., Cardona V.R. (2015) Prevalencia e impacto clínico de la sensibilización a látex y frutas en estudiantes de odontología de la Universidad de Antioquia y su relación con alergia a frutas. 2015; 28 (2).

101. Sánchez-Quiles I., Nájera-Pérez M.D., Calleja-Hernández M., Martinez-Martínez F., Belchí-HernándezJ, Canteras M.(2013) Mejora del conocimiento sobre reacciones alérgicas cruzadas en dos grupos de medicamentos: $\beta$-lactámicos y AINEs. Farmacia Hospitalaria https://dx.doi.org/10.7399/FH.2013.37.6.1005

102. Yagami A., Nakazawa Y., Suzuki K., Matsunaga K. (2009) Curry spice allergy associated with pollen-food allergy syndrome and latex fruit-syndrome. Journal of Derma- tology 36: 45-49 https://www.ncbi.nlm.nih. gov/pubmed/19207436

103. Cabañes N., Igea J.M., De la Hoz B. (2012) Latex Allergy: Position Paper. J Investig Allergol Clin_Immuno. 22 (5): 313-330.

104. Yagami A., Suzuki K., Saito H., Matsunagra K. (2009) Hev b 6.02 Is the Most Important Allergen in Health Care Workers Sensitized Occupationally by Natural Rubber Latex Gloves. Allergol Int. 58: 347-355.

105. Sociedad Española de Alergología e Inmunología Clínica y Alergia e Inmunología (2005) Alergológica: Factores epidemiológicos, clínicos y socioeconómicos de las enfermedades alérgicas en España en 2005. Luzán 5 S.A. Ediciones, Madrid.

106. Scurlock A., Wesley A. (2007) Hipersensibilidad a los alimentos. In: Fireman P (ed) Atlas de Alergia e Inmunología Clínica, 3rd edn Elsevier, España pp. 213-224. 


\section{ANNEX 1. INFORMED CONSENT}

\section{Consentimiento Informado Para estudio de" Prevalencia de alergia en la población odontológica de Costa Rica"}

Investigadores: Dr. Jorge Oviedo Quirós y Dra. Patricia Lorz Ulloa.

Teléfonos: 2511-8067. Disponibilidad en horario de oficina.

Introducción

Lo instamos a formar parte de este estudio de investigación sobre "Prevalencia de alergia en la población odontológica de Costa Rica" desarrollado por investigadores de la Facultad de Odontología de la Universidad de Costa Rica. En caso que tenga alguna duda o inquietud sobre el contenido de este documento o de la investigación a la cual se le está invitando a participar, se le explicará exhaustivamente hasta resolver la misma. Si después de haber leído toda la información usted decide participar en este estudio, deberá firmar en el lugar indicado.

\section{Propósito del estudio}

Identificar mediante una hoja de recolección de datos (que consta de preguntas de rellenar), la prevalencia de atopia y alergia en la población de estudiantes de odontología, odontólogos y personal auxiliar.

\section{Procedimientos}

Se le solicitarán dentro del cuestionario para la determinación de la prevalencia de alergias en la población en estudio datos personales, tiempo que ha estado expuesto al ambiente odontológico, antecedentes de comorbilidad personales, antecedentes familiares de alergia y una última sección donde se consulta específicamente por el desarrollo de manifestaciones alérgicas a: alimentos, medicamentos y materiales odontológicos.

En caso de cumplir con los criterios de inclusión del estudio, se le solicitará leer y llenar de forma personal la encuesta mencionada que le entregará el colaborador en la investigación (el cual se encuentra debidamente identificado).

\section{Molestias o riesgos}

No existe ningún riesgo o molestia por participar de este estudio, el hecho que acepte participar en este estudio no lo expone a un riesgo.

Algunas de las preguntas del cuestionario o de la encuesta que se le van a hacer pueden incomodarlo. Usted puede escoger si contesta o no una o varias de las preguntas que lo hagan sentir incómodo.

En dado caso que usted no desee participar de la recolección de datos, sus derechos como estudiantes de odontología, odontólogos y personal auxiliar serán siempre respetados y no recibirá ningún tipo de trato discriminatorio.

\section{Beneficio}

A nivel social, la realización de esta investigación tratará que la población conozca la prevalencia de reacciones alérgicas asociadas al ambiente odontológico. Una vez que se obtenga la identificación de la población de riesgo, se buscarán alternativas para la prevención de los eventos.

\section{Confidencialidad}

Sólo los investigadores y el tutor de la investigación tendrán acceso a la información que nos brinde, a excepción de que la Ley solicite dicha información. Su identificación y sus datos serán confidenciales. Su nombre se mantendrá anónimo, se codificará y no será posible que alguna persona ajena a nosotros los investigadores puedan relacionarlos de alguna manera con su persona.

\section{Consentimiento}

He leído y comprendo este consentimiento informado. He recibido respuesta a todas mis preguntas. Acepto voluntariamente sin presión alguna a participar en este estudio. Al firmar este documento no estoy renunciando a mis derechos legales, que de todas maneras tengo como participante en un estudio de investigación.

Participante

Testigo

Investigador
Firma

Firma

Firma
Fecha

Fecha

Fecha 


\section{UNIVERSIDAD DE COSTA RICA \\ FACULTAD DE ODONTOLOGIA - PROYECTO MACRO

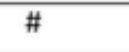 \\ INSTRUMENTO DE INVESTIGACION APLICADO A ODONTÓLOGOS EN COSTA RICA EN \\ EL PERIODO 2016}

\section{“Caracterización de las atopias en odontólogos de Costa Rica, en}

\section{período 2016".}

Estimado colega, este cuestionario tiene como finalidad conocer el comportamiento de atopias en la población de odontólogos de Costa Rica. Marque con una X en la casilla $\bigcirc$ que corresponda o complete en el espacio requerido. Puede haber opciones múltiples.

1. ¿Presentó usted antecedentes de alergia ANTES de entrar a la carrera de odontología?
0. $\bigcirc$ No (Pase a la pregunta 2 )
1. $\mathrm{Si}$

1.1 Indique la o las reacciones alérgicas que presentaba

0. Asma alérgica

1. Rinitis (estornudos y picazón de nariz)

2. Dermatitis (descamación y / o eczema)

3. Urticaria (picazón)
4. Problemas gastrointestinales a alimentos

5. Conjuntivitis (picazón de ojos)

6. Otros:

8. No Aplica

9. No Sabe/ No Responde

2. ¿Tiene familiares en PRIMER GRADO DE CONSANGUINIDAD (padres, hermanos e hijos) que hayan presentado algún tipo de reacción alérgica?

0. No (Pase a la pregunta 3) 1. $\bigcirc \mathrm{Si}$

Escriba una $X$ en la casilla que corresponde al familiar en PRIMER GRADO DE CONSANGUINIDAD que ha presentado algún tipo de reacción alérgica y los antecedentes correspondientes a la misma: 
ANNEX 2. SURVEY INSTRUMENT PAGE 2

\begin{tabular}{|c|c|c|c|c|c|c|c|c|}
\hline & 2.2 & \multirow[t]{2}{*}{$\begin{array}{l}\text { Asma } \\
\text { Alérgica }\end{array}$} & \multirow{2}{*}{$\begin{array}{l}\text { Rinitis } \\
\text { (Estornudos } \\
\text { y picazón de } \\
\text { nariz) }\end{array}$} & \multirow{2}{*}{$\begin{array}{l}\text { Dermatitis } \\
\text { (descamación } \\
\text { y/o eczema) }\end{array}$} & \multirow[t]{2}{*}{$\begin{array}{l}\text { Urticaria } \\
\text { (Picazón) }\end{array}$} & \multirow{2}{*}{$\begin{array}{l}\text { Problemas } \\
\text { gastrointes- } \\
\text { tinales } \\
\text { a alimentos }\end{array}$} & \multirow{2}{*}{$\begin{array}{l}\text { Conjuntivitis } \\
\text { (picazón de } \\
\text { ojos) }\end{array}$} & \multirow[t]{2}{*}{ Otros: } \\
\hline 2.1 & & & & & & & & \\
\hline \multicolumn{9}{|l|}{ Papá } \\
\hline \multicolumn{9}{|c|}{ Mamá } \\
\hline \multicolumn{9}{|c|}{ Hermanos } \\
\hline Hijos & & & & & & & & \\
\hline
\end{tabular}

\section{3. ¿Actualmente, presenta usted alergia a ALIMENTOS?}

\section{0. $\bigcirc$ No (Pase a la pregunta 4)}

1. $\bigcirc \mathrm{Si}$

3.1 Marque en los siguientes espacios, el alimento y el tipo de reacción alérgica con la letra que corresponde al rango de tiempo según la siguiente clasificación:

$A=$ Si se presentó de 0 a $120 \mathrm{~min} . \quad B=120 \mathrm{~min}$ a las $12 \mathrm{~h} . \quad C=12 \mathrm{~h}$ a las $48 \mathrm{~h} . \quad \mathrm{D}=48 \mathrm{~h}$ o más.

\begin{tabular}{|c|c|c|c|c|c|c|c|}
\hline Alimento & $\begin{array}{l}\text { Asma } \\
\text { alérgica }\end{array}$ & $\begin{array}{l}\text { Rinitis } \\
\text { (Estornudos } \\
\text { y picazón de } \\
\text { nariz) }\end{array}$ & $\begin{array}{l}\text { Dermatitis } \\
\text { (descamación } \\
\text { y/o eczema) }\end{array}$ & $\begin{array}{l}\text { Urticaria } \\
\text { (Picazón) }\end{array}$ & $\begin{array}{l}\text { Problemas } \\
\text { gastrointes- } \\
\text { tinales }\end{array}$ & $\begin{array}{l}\text { Conjuntivitis } \\
\text { (picazón de } \\
\text { ojos) }\end{array}$ & Otros: \\
\hline \multicolumn{8}{|l|}{ Alcohol } \\
\hline \multicolumn{8}{|l|}{ Café } \\
\hline \multicolumn{8}{|l|}{ Camarón } \\
\hline \multicolumn{8}{|l|}{ Cerdo } \\
\hline \multicolumn{8}{|l|}{ Chocolate } \\
\hline \multicolumn{8}{|c|}{ Colorantes } \\
\hline \multicolumn{8}{|l|}{ Lactosa } \\
\hline \multicolumn{8}{|l|}{ Naranja } \\
\hline \multicolumn{8}{|l|}{ Piña } \\
\hline \multicolumn{8}{|l|}{ Tomate } \\
\hline Otros:- & & & & & & & \\
\hline
\end{tabular}

\section{4. ¿Actualmente, presenta alergia a algún MEDICAMENTO?}
0. $\bigcirc$ No (Pase a la pregunta 5)
1. $\bigcirc \mathrm{Si}$

4.1 Marque en los siguientes espacios, el medicamento y el tipo de reacción alérgica con la letra que corresponda al rango de tiempo de aparición según la siguiente clasificación: 
ANNEX 2. SURVEY INSTRUMENT PAGE 3

$A=$ Si se presentó de 0 a $120 \mathrm{~min} . \quad B=120 \mathrm{~min}$ a las $12 \mathrm{~h} . \quad C=12 \mathrm{~h}$ a las $48 \mathrm{~h} . \quad \mathrm{D}=48 \mathrm{~h}$ o más.

\begin{tabular}{|c|c|c|c|c|c|c|c|}
\hline Medicamento & $\begin{array}{l}\text { Asma } \\
\text { alérgica }\end{array}$ & $\begin{array}{l}\text { Rinitis } \\
\text { (Estornudos } \\
\text { y picazón de } \\
\text { nariz) }\end{array}$ & $\begin{array}{l}\text { Dermatitis } \\
\text { (descamación } \\
\text { y/o eczema) }\end{array}$ & $\begin{array}{l}\text { Urticaria } \\
\text { (Picazón) }\end{array}$ & $\begin{array}{l}\text { Problemas } \\
\text { gastrointes- } \\
\text { tinales }\end{array}$ & $\begin{array}{l}\text { Conjuntivitis } \\
\text { (picazón de } \\
\text { ojos) }\end{array}$ & Otros: \\
\hline \multicolumn{8}{|l|}{ AINES } \\
\hline \multicolumn{8}{|l|}{ Antihistaminic } \\
\hline \multicolumn{8}{|l|}{ Cefalosporina } \\
\hline \multicolumn{8}{|l|}{ Paracetamol } \\
\hline \multicolumn{8}{|l|}{ Penicilina } \\
\hline \multicolumn{8}{|l|}{ Tetraciclina } \\
\hline Otros: & & & & & & & \\
\hline
\end{tabular}

\section{5. ¿Presenta usted alergia a MATERIALES o MEDICAMENTOS utilizados durante la práctica odontológica?}
0. $\bigcirc$ No (Pase a la pregunta 6$)$
1. $\bigcirc \mathrm{Si}$

5.1 Marque en los siguientes espacios, el material/medicamento y el tipo de reacción alérgica con la letra que corresponde al rango de tiempo de aparición según la siguiente clasificación:

$A=S i$ se presentó de 0 a $120 \mathrm{~min} . \quad B=120 \mathrm{~min}$ a las $12 \mathrm{~h} . \quad C=12 \mathrm{~h}$ a las $48 \mathrm{~h} . \quad \mathrm{D}=48 \mathrm{~h}$ o más.

\begin{tabular}{|c|c|c|c|c|c|c|c|}
\hline Material o & $\begin{array}{l}\text { Asma } \\
\text { Alérgica }\end{array}$ & $\begin{array}{l}\text { Rinitis } \\
\text { (Estornudos } \\
\text { y picazón de } \\
\text { nariz) }\end{array}$ & $\begin{array}{l}\text { Dermatitis } \\
\text { (descamación } \\
\text { y/o eczema) }\end{array}$ & $\begin{array}{l}\text { Urticaria } \\
\text { (Picazón) }\end{array}$ & $\begin{array}{l}\text { Problemas } \\
\text { gastrointes- } \\
\text { tinales }\end{array}$ & $\begin{array}{l}\text { Conjuntivitis } \\
\text { (picazón de } \\
\text { ojos) }\end{array}$ & Otros: \\
\hline \multicolumn{8}{|l|}{ Acrilico } \\
\hline Alginato & & & & & & & \\
\hline Anestesia Tópica & & & & & & & \\
\hline
\end{tabular}




\section{ANNEX 2. SURVEY INSTRUMENT PAGE 4}

\begin{tabular}{|l|l|l|l|l|l|l|l|}
\hline Cera Dental & & & & & & & \\
\hline Cubrebocas & & & & & & & \\
\hline Endo Ice & & & & & & & \\
\hline Glutaraldehido & & & & & & & \\
\hline Guantes & & & & & & & \\
\hline Hipoclorito & & & & & & & \\
\hline Látex & & & & & & & \\
\hline Piedra dental & & & & & & & \\
\hline Polvo de guantes & & & & & & & \\
\hline Resinas & & & & & & & \\
\hline Otros:-_- & & & & & & & \\
\hline
\end{tabular}

\section{Para ir finalizando, HA PADECIDO usted o padece de:}

0. Hipertensión arterial

1. Diabetes

2. Artritis reumatoide

3. $\bigcirc$ Colesterol y Triglicéridos

4. $\bigcirc$ Lupus eritematoso
5. $\bigcirc$ Obesidad

6. Problemas de Tiroides

7. Ninguna

8. Otros:

\section{Solicitamos los siguientes datos personales:}

7.1 Edad:
7.2 Sexo:
0. $\bigcirc$ Femenino
1. Masculino.

7.3 Área que trabaja:

0. $\bigcirc$ Odontología General

1. Especialista en:

7.4 Universidad en la que obtuvo el grado de licenciatura en odontología:

7.5 ¿Cuántos años, ha estado expuesto a ambientes relacionados con la odontología? Años.

\section{Le agradecemos el tiempo para llenar este cuestionario.}

\section{¡Muchas Gracias!}

